\title{
Bladder Cancer Stem-Like Cells: Their Origin and Therapeutic Perspectives
}

\author{
Tomokazu Ohishi ${ }^{1,2}$, Fumitaka Koga ${ }^{3}$ and Toshiro Migita ${ }^{2,4, *}$
}

Received: 6 November 2015; Accepted: 24 December 2015; Published: 29 December 2015

Academic Editor: William Chi-shing Cho

1 Institute of Microbial Chemistry (BIKAKEN), Numazu, 18-24 Miyamoto, Numazu-shi, Shizuoka 410-0301, Japan; ohishit@bikaken.or.jp

2 Division of Molecular Biotherapy, Japanese Foundation for Cancer Research, 3-8-31 Ariake, Koto-ku, Tokyo 135-8550, Japan

3 Department of Urology, Tokyo Metropolitan Cancer and Infectious Diseases Center, Komagome Hospital, Tokyo 113-8677, Japan; f-koga@cick.jp

4 Department of Urology, Kashiwa Kousei General Hospital, 617 Shikoda, Kashiwa-shi, Chiba 277-8551, Japan

* Correspondence: toshiro.migita@jfcr.or.jp; Tel.: +81-4-7145-1111 or +81-3-3520-0111 (ext. 5745);

Fax: +81-3-3570-0484

\begin{abstract}
Bladder cancer (BC), the most common cancer arising from the human urinary tract, consists of two major clinicopathological phenotypes: muscle-invasive bladder cancer (MIBC) and non-muscle-invasive bladder cancer (NMIBC). MIBC frequently metastasizes and is associated with an unfavorable prognosis. A certain proportion of patients with metastatic $\mathrm{BC}$ can achieve a remission with systemic chemotherapy; however, the disease relapses in most cases. Evidence suggests that MIBC comprises a small population of cancer stem cells (CSCs), which may be resistant to these treatments and may be able to form new tumors in the bladder or other organs. Therefore, the unambiguous identification of bladder CSCs and the development of targeted therapies are urgently needed. Nevertheless, it remains unclear where bladder CSCs originate and how they are generated. We review recent studies on bladder CSCs, specifically focusing on their proposed origin and the possible therapeutic options based on the CSC theory.
\end{abstract}

Keywords: cancer stem cell; bladder cancer

\section{Introduction}

Tissues can regenerate in the event of partial loss or damage. Stem cells are both pluripotent and have self-renewal potential, thereby contributing to tissue regeneration. Tumor cells are heterogeneous and are assumed to include stem cell-like cancer cells, or so-called cancer stem cells (CSCs). The first experimental evidence of CSCs was described in previous landmark studies in hematology [1,2]. According to the consensus definition of CSCs [3], these cells have the capacity for self-renewal and for generating heterogeneous lineages of cancer cells that compose the tumor. However, it is technically difficult to demonstrate the pluripotency and self-renewal potential of cancer cells in vivo, especially in solid tumors. Currently, the tumorigenicity of a small number of cancer cells in immunodeficient mice is used as the gold standard for the confirmation of CSCs. Thus, the term CSCs is considered to be a conceptual or empirical term. Tumor-initiating cells, tumor-propagating cells [4], or tumor-perpetuating cells [5] may be a more accurate term; however, we use the term CSCs to include cancer stem-like cells. CSCs were first identified in leukemia and were then found in solid tumors, such as breast [6], brain [7], colorectal [8-10], head and neck [11], pancreatic [12], and prostate cancers [13], as well as melanoma [14]. 
Bladder cancer (BC), which originates from the urothelial epithelium, is the most common cancer of the human urinary tract. $\mathrm{BC}$ is the ninth most common cancer worldwide and is relatively common in developed countries [15]. Men have a higher incidence of BC than women (ratio 3.5:1) [15]. $\mathrm{BC}$ is divided into two clinicopathologic entities: non-muscle-invasive bladder cancer (NMIBC) and muscle-invasive bladder cancer (MIBC). Approximately $80 \%$ of BC patients present with NMIBC, which is associated with a lower risk of mortality despite the high risk of intravesical tumor recurrence. In contrast, the remaining $20 \%$ of patients present with MIBC, which frequently metastasizes to other distant organs, including the liver, lung, and bone. Patients with MIBC have a higher risk of mortality. The pathological differences between NMIBC and MIBC are remarkable. Most cases of NMIBC are characterized by a papillary structure, whereas MIBC does not have such a uniform structural pattern. Compared with NMIBC, MIBC consists of a wider variety of cancer cells that range from differentiated to undifferentiated. Urothelial stem cells localize in the basal cell layer and can generate all types of urothelial cells [16-19]. When the urothelium is partially damaged or lost, urothelial stem cells can regenerate and compensate for the damaged or lost tissue. However, the regenerative potential of stem cells is well coordinated and strictly regulated in the normal urothelial lineage, thereby preventing tumor formation. $\mathrm{BC}$ cells are considered to arise from a single urothelial cell that has accumulated genetic or epigenetic DNA alterations. Bladder CSCs were first identified in 2009 by sorting with markers of normal basal cells [20]. Recent studies have demonstrated new approaches for identifying bladder CSCs, and the results of these studies increasingly suggest the existence of bladder CSCs [21-27]. However, the origin of bladder CSCs and the mechanism of their generation are largely unknown [21]. This review focuses on the putative origin of bladder CSCs and addresses the potential therapeutic approaches for advanced BC based on the CSC theory.

\section{Tumor Heterogeneity and the Cancer Stem Cell (CSC) Theory}

Tumors are believed to originate from a single cancer cell. It has long been discussed how this initial cancer cell generates other different types of cancer cells to form a tumor. Tumor heterogeneity may be caused by the heterogeneity of cancer cells at both the innate genetic and phenotypic levels. Because of genetic instability in cancer cells, random mutations accumulate during cell division, and the progeny may have distinct genotypes from the parental cancer cells. Genomic and epigenomic variations have been observed in each subpopulation of cancer cells within a single tumor [28-30]. During proliferation, each cancer cell encounters a hostile environment; therefore, cancer cells have to modify and adjust their phenotype according to the tumor microenvironment. Solid tumors less than 1-2 $\mathrm{mm}$ in diameter can obtain sufficient nutrition and oxygen from their surrounding environment, but the cells in the center of a larger solid tumor usually grow slower than those in the marginal region [31,32]. Accordingly, tumors are composed of various cancer cells that have distinct genomic, epigenomic, and phenotypic alterations, and tumor heterogeneity is an inherent and fundamental property of solid tumors.

Two major hypotheses may explain how tumors develop. In the stochastic model, all tumor cells have tumorigenic potential, and each heterogenic tumor cell can individually form tumors. In the hierarchy model, only a small population of CSCs have the ability to produce various progenitor tumor cells and to form tumors, but the non-CSCs cells do not have these properties. Recent studies support the hierarchy model, emphasizing the significance of CSCs, and propose evolutional models based on the CSC theory [33-36].

CSCs in tumors have several common properties, including a slower growth rate and transition to a dormant cell population compared with the majority of other tumor cells. This characteristic of CSCs has important clinical implications because it is associated with resistance to anticancer therapeutics $[3,5,34,37]$. Classical chemotherapy and radiotherapy cause less damage to DNA in slow-dividing cells, such as CSCs. In addition, CSCs display higher levels of drug efflux proteins, such as P-glycoproteins and ATP-binding cassette transporters [38]. Therefore, a causal relationship between CSCs and drug resistance has been suggested; however, the efflux mechanism is not likely to 
be crucial for CSCs [37]. Another common property of CSCs is high tumorigenicity. A relatively smaller number of CSCs can form tumors in xenograft models compared with non-CSCs. A single melanoma cell can form tumors, independent of CSCs markers [39]; therefore, the robustness of tumorigenicity varies among cell lines or with the method of CSC isolation. In the clinical setting, after significantly reducing the tumor burden by surgery, chemotherapy or radiation therapy, tumors can recur from a small number of residual CSCs. Additionally, high tumorigenicity is associated with the potential for tumor regrowth in other organs, known as distant metastasis.

Tissue stem cells originally develop from a single embryonic cell. The cellular differentiation of tissue stem cells is completely programmed in the DNA of the embryonic cell. On the other hand, cancer is a disease caused by cells that have lost the programming for terminal differentiation [40]. Thus, all cancer cells are considered to be undifferentiated cells, and CSCs are likely to be the most immature, undifferentiated cancer cells. Normal stem cells have a homeostatic ability to balance differentiation and self-renewal based on environmental stimuli and genetic constraints [41]; however, this balance in CSCs is inclined toward self-renewal because CSCs remain in an undifferentiated state. Moreover, cancer cells are immortal and grow indefinitely despite the growth-suppressing effects by surrounding normal cells, limited energy supply, and immunological surveillance. Cancer cell proliferation is not restricted by any type of host cell, which is partially caused by miscommunication between cancer cells and surrounding normal cells. Compared with hematologic CSCs, this characteristic of CSCs in solid tumors is critical because it allows them to form disorganized tumor tissues. Collectively, the developmental evolution of normal and cancer cells could be represented graphically by a relationship between their differentiation potential (horizontal axis) and organizing ability (vertical axis) (Figure 1). In this context, tumor-generating CSCs may arise from a type of normal or cancer cell, but CSCs are likely to be cells with high self-renewal potential and high organizing potential. Alternatively, non-CSCs may have self-renewal potential to some extent; however, they are unlikely to have tissue-organizing properties.

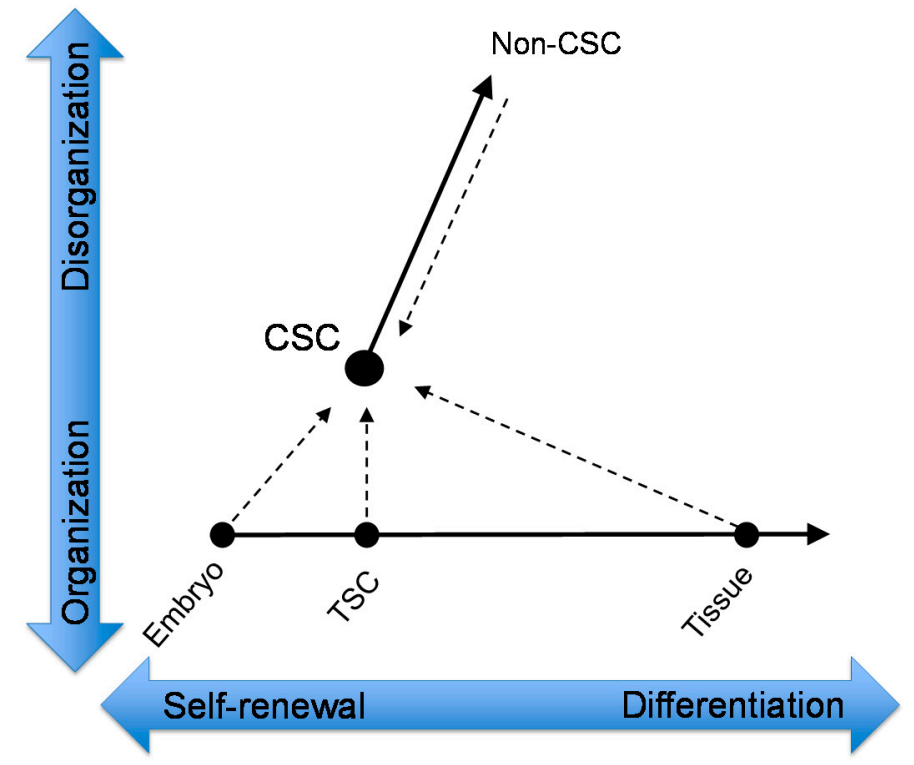

Figure 1. Schematic model of cancer stem cell (CSC) generation. The embryo undergoes a series of cleavage divisions and generates multipotent embryonic stem cells (ESCs). The ESCs generate tissue stem cells (TSCs), which are indispensable for tissue generation. The TSCs include urothelial stem cells, which produce all types of urothelial cells via differentiation. CSCs are separate from the normal differentiation process because of their lack of organization (dotted arrows). CSCs generate more differentiated cancer cells, known as non-CSCs. 


\section{The Possible Existence of Bladder CSCs}

Bladder tissue functions as a reservoir for urine and protects the host from urinary constituents. Urothelial cells including stem cells are usually quiescent; however, they will proliferate and stem cells supply new urothelial cells for the repair and reconstitution of bladder tissue when the bladder mucosa is damaged by various pathogens (mainly via infections) [42]. Bladder tissue includes many types of stem cells, such as urothelial stem cells, adipose-derived stem cells, bone marrow-derived mesenchymal stromal cells, mesenchymal stem cells, urine-derived stem cells $[43,44]$. BC may originate from such stem cells or from more differentiated progenitor cells as a result of genetic or epigenetic alterations. Recent molecular biology studies have demonstrated that $\mathrm{BC}$ results from specific genetic mutations, and such genetic variations corresponded well to the clinicopathological phenotype $[45,46]$. The occurrence of NMIBC and MIBC may depend on their originating site and aberrations in a specific signaling pathway. NMIBC exhibits frequent mutations of fibroblast growth factor receptor 3 (FGFR3), HRAS, and PIK3CA in differentiated (uroplakin ${ }^{+}$and cytokeratin- $20^{+}$) or intermediate (cytokeratin- $18^{+}$, $\mathrm{p} 63^{+/-}$, cytokeratin- $5^{+/-}$, and CD $44^{+/-}$) urothelial cells, whereas MIBC exhibits mutations of the tumor suppressor genes $p 53, R b$, and PTEN in basal cells (cytokeratin- $5^{+/-}$, cytokeratin- $17^{+}, \mathrm{CD} 44^{+/-}$, and $\left.\mathrm{p} 63^{+}\right)[22,23,47]$.

The molecular profiling of established BC cell lines has demonstrated distinct expression patterns between NMBIC and MIBC. A wide variety of stem cell markers are up-regulated in CSCs obtained from MIBC cell lines [48]. Importantly, most bladder CSCs have been identified in highly metastatic MIBC but not in NMIBC [20,49-53]. The majority of metastatic BCs initially respond to systemic chemotherapy, but metastatic lesions may subsequently appear despite the continuous administration of treatment. The existence of bladder CSCs may explain observations in the clinical setting, including the most important clinical issues: chemoresistance and metastasis.

The hierarchy model and the CSC theory are entirely dependent on the well-defined detection and verification of CSCs within a tumor. The following techniques have been developed to identify CSCs, including bladder CSCs: a side population method with DNA-binding Hoechst 33342 or DyeCycle Violet [48,50,51], aldehyde dehydrogenases (ALDH) activity [52,54], in vitro sphere formation [55,56], and CSC markers [22,24]. Currently, a flow cytometric technique with CSC markers is widely used to detect CSCs. CD44 is a member of the transmembrane glycoprotein family and has been implicated as a CSC marker in many malignancies, including head and neck [11], gastric [57], prostate [58], colorectal [10], and pancreatic cancer [12]. In BC, CD44 ${ }^{+}$cells exhibit an enhanced capacity to form xenografts in immune-compromised mice and exhibit chemoresistance compared with CD44- cells $[20,59]$. CD44v6, a CD44 variant isoform containing the CD44v6 exon, has been shown to be enriched in bladder CSCs [53,60]. Other bladder CSC markers have been reported, including CD133 [61,62], 67-kDa laminin receptor (67LR) [49], CD47 [20], CD49 [63], and keratin 14 (KRT14) [64]. The sequential transplantation of xenograft tumors is increasingly required for the confirmation of CSCs [3,5,35]; however, studies on BC remain scarce. Collectively, the existence of bladder CSCs remains uncertain; however, it is evident that $\mathrm{BC}$ displays tumor heterogeneity, and certain $\mathrm{BC}$ cells have unique and advantageous properties for their survival and development.

\section{Hypothetical Origin of Bladder CSCs}

The discovery of induced pluripotent stem (iPS) cells has impacted stem cell biology and oncology. CSCs can be experimentally obtained through the generation of iPS cells [65]. Immature reprogrammed iPS cells can develop renal cancer in chimeric mice, which suggests that the epigenetic alterations of normal cells promotes the generation of tumor-initiating cancer cells [66]. Furthermore, the implantation of embryonic stem (ES) cells or iPS cells in mice results in teratoma formation and cancer $[67,68]$. In addition to iPS cells, human mesenchymal stem/stromal cells spontaneously transform after long-term culture [69]. These findings suggest that multipotent stem cells are likely to transform into CSCs, thereby resulting in tumorigenesis. However, importantly, mutations or chromosomal rearrangements in progenitor cells and differentiated cells as well as in stem cells, may 
give rise to CSCs [70]. Malignant transformation may result from the activation of the oncogenic pathway, independent of the cell-of-origin [71]. Thus, although stem cells are most likely to be the origin of CSCs, it cannot exclude the possibility of more differentiated epithelial cells as the origin of CSCs.

Another hypothesis for the origin of CSCs is that cancer cells may generate these cells on an autonomous basis. Increasing evidence of cancer cell plasticity between CSCs and non-CSCs [36,72] indicates that non-CSCs can generate CSCs. The overexpression of oncogenes in vitro can transform human fibroblasts into the CSC phenotype, including properties of self-renewal, multipotency, and the generation of heterogeneous tumors [73]. Pre-existing cancer cells have genetic instability; therefore, these cells easily acquire random mutations, chromatin modifications, and epigenetic reprogramming. The generation of iPS cells allows us to hypothesize that differentiated cancer cells could be reverted into CSCs by the activation of defined transcriptional factors [68]. Several reports have suggested that the phenotype of cancer cells transforms into that of CSCs when cells are transfected with the defined factors Oct3/4, Sox2, Klf4, and c-Myc [74].

Taken together, these results indicate that CSCs may originate from both normal cells and pre-existing cancer cells. In the next section, we discuss the possible origins of bladder CSCs.

\subsection{Normal Urothelium}

The bladder urothelial mucosa is composed of three types of urothelial cells: basal, intermediate, and differentiated umbrella [16-18]. Importantly, a genetic mouse model for BC has demonstrated that BCs arise from these distinct urothelia [75]. McConkey's group performed a clustering analysis of the gene expression profile of MIBC and demonstrated that this cancer can be further classified into basal, luminal, and $p 53$-like subtypes based on site-specific molecular markers and resistance to chemotherapy [76]. Thus, bladder CSCs may originate from these intrinsic normal cells (Figure 2).

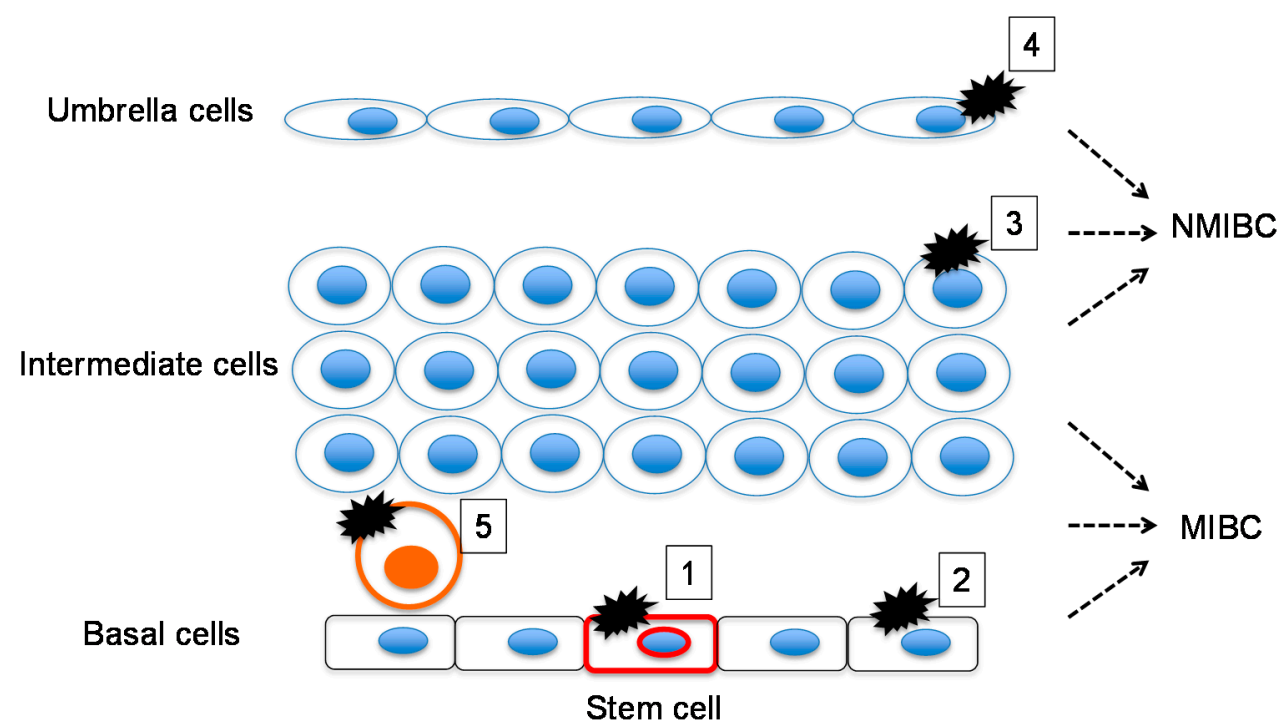

1. Urothelial stem cell, 2. Basal cell, 3. Intermediate cell, 4. Umbrella cell, 5. Bone marrow-derived cell

Figure 2. Normal bladder tissue may be a possible origin of bladder CSCs by direct transformation into CSCs via mutations in urothelial stem cells, basal cells, intermediate cells, and terminally differentiated umbrella cells. Urothelial stem cells, basal cells and intermediate cells give rise to muscle-invasive bladder cancer (MIBC), whereas umbrella and intermediate cells give rise to non-muscle-invasive bladder cancer (NMIBC). 


\subsubsection{Urothelial Stem Cell}

Intestinal stem cells expressing Lgr5 are suggested to be the origin of colon CSCs [77]. This finding indicates that CSCs may directly originate from normal stem cells. A pulse-chase study with the nucleotide analogue bromodeoxyuridine demonstrated that cells with label-retaining DNA, which are considered to be urothelial stem cells, were localized to the basal cell layer [19]. Another study using mitochondrial DNA mutations supports this finding [44]. The nitrosamine-induced BC model suggests that MIBC originates from stem cells in the basal cell layer [78]. These results suggest that urothelial stem cells located in the basal cell layer are most likely the origin of bladder CSCs.

\subsubsection{Other Stem Cells in the Normal Urothelium}

In addition to urothelial stem cells, bone marrow-derived stem cells, adipose-derived stem cells and urine-derived stem cells are used as sources for bladder repair [43]. Additionally, these stem cells are a possible origin of bladder CSCs. Helicobacter pylori, a carcinogen, causes gastric cancer through the recruitment of bone marrow-derived cells (BMDCs) [79]. However, in the chemical-induced BC model, BMDCs were associated with inflammation surrounding the tumor but not with tumorigenesis [80].

\subsubsection{Basal Cells}

The first report of bladder CSCs demonstrated that these cells were enriched in basal cell markers (Lineage-CD44 ${ }^{+} \mathrm{CK} 5^{+} \mathrm{CK} 20^{-}$) [20]. The putative markers of bladder CSCs are mostly overlapped with those of basal cells [25]. Furthermore, the gene expression meta-dataset demonstrated that the gene signature of basal-like MIBC is enriched for genes expressed by basal-like breast cancer and tumor-initiating cells [81]. Shin et al. reported that MIBC arises exclusively from Sonic hedgehog (Hh)-expressing basal cells in vivo [82]. Keratin-5-expressing basal cells give rise to carcinoma in situ, MIBC, and squamous cell carcinoma (SCC) [75]. These findings support the hypothesis that bladder CSCs originate from basal cells.

\subsubsection{Intermediate Cells}

Intermediate cells show variable expression of a bladder CSC marker, CD44 [53]. The linage-tracing experiment in a murine carcinogenesis model showed that intermediate cells give rise primarily to papillary bladder tumors [75]. Additionally, Brandt et al., suggested that the malignant transformation of intermediate cells by FGFR3 expression leads to hyperplasia and low-grade papillary tumors [26]. These findings suggest that intermediate cells are a possible origin of CSCs in NMIBC.

\subsubsection{Umbrella Cells}

Luminal-type MIBC may originate from umbrella cells via the aberrant expression of transcriptional factors, such as PPARG, ESR1, and FGFR3 [76]. In addition, another report showed that luminal-typed MIBC expresses umbrella cell markers, such as uroplakins and low-molecular-weight keratin 20 [81]. Thus, MIBC may originate from umbrella cells, which may transform into bladder CSCs.

\subsection{Bladder Cancer (BC) Cells}

Cancer stemness is influenced by three components: genetic diversity, altered epigenetics, and the tumor microenvironment [34]. The tumor microenvironment is important for cancer cell survival, particularly in solid tumors, because solid tumor cells face challenges during growth, such as hypoxia, low nutrition, and interactions with surrounding normal cells, including tumor-associated fibroblasts, macrophages, the perivascular stroma, and endothelial cells. The tumor microenvironment contributes to CSC maintenance by providing a stem cell niche. Tumor angiogenesis-mediated cancer vascular niche is important for the maintenance and proliferation of CSCs [83]. Stem-like characteristics of BC are not observed until late in tumor development [27]. These findings suggest that the generation of 
bladder CSCs is a late event in tumorigenesis, and pre-existing BC is likely to supply CSCs via various mechanisms as discussed below (Figure 3).

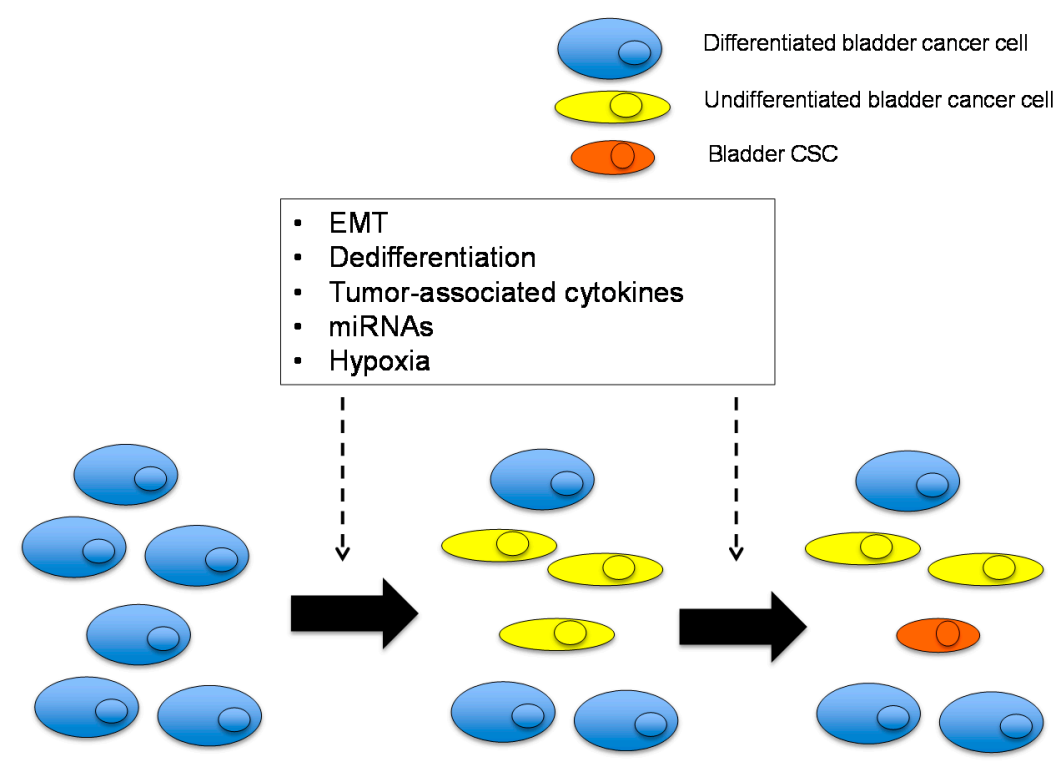

Figure 3. Possible mechanisms of bladder CSC generation from more differentiated bladder cancer (BC) cells. Differentiated and undifferentiated BC cells, which are defined as non-CSCs, are a possible origin of bladder CSCs. This phenomenon is caused by cell-autonomous mechanisms and the tumor microenvironment, including epithelial-mesenchymal transition (EMT), dedifferentiation, tumor-associated cytokines, miRNAs, and hypoxia.

\subsubsection{Epithelial-Mesenchymal Transition (EMT)}

The EMT concept emerged from histological findings of embryonic cell development. EMT has been observed in cancer and is an important phenomenon, particularly in tumor invasion and metastasis. Cancer cells originate from epithelial cells; therefore, these cells should initially have many epithelial features. However, during tumor progression, cancer cells may lose their epithelial features and transform into the mesenchymal phenotype. Cancer cells with different phenotypes have been simultaneously observed in a single tumor, including BC [84]. Importantly, Mani et al., demonstrated that breast CSCs are generated via EMT of cancer cells $[85,86]$. The forced expression of the EMT-inducing transcription factors Twist and Snail in immortalized human mammary epithelial cells results in the acquisition of mesenchymal traits, the expression of stemness markers, and the ability to form spheres [85]. Subsequently, increasing evidence suggests that EMT is a mechanism for generating CSCs. The transforming growth factor $\beta$ (TGF- $\beta$ ) signaling pathway is involved in both physiological and pathological EMT. The TGF- $\beta$ pathway is activated in BC and contributes to tumor progression via EMT [87-89]. In addition to the TGF- $\beta$ pathway, hypoxia and its related molecules, hypoxia-inducible factors (HIFs), induce EMT and promote self-renewal in CSCs [90]. The expression of HIF- $2 \alpha$ in tumor-associated macrophages is a poor prognostic factor in MIBC [91]. MicroRNAs (miRNAs) are small noncoding RNAs that negatively regulate the expression levels of protein-coding genes and play an important role in various biological processes, including EMT and cancer stemness [92,93]. miRNA-200 regulates EMT in BC, and its expression increases the sensitivity of cancer cells to epidermal growth factor receptor (EGFR) inhibitors [94]. The expression of various other miRNAs are dysregulated in BC, all of which contribute to tumor suppression or promotion [95-97]. 


\subsubsection{Tumor-Associated Cytokines}

The stemness of breast CSCs is regulated by the cytokine network between mesenchymal stem cells and cancer cells [98]. Plasma IL-6 levels are higher in patients with BC than in healthy controls [99]. Interleukin 6 (IL-6) is a major activator of the Stat3 signaling pathway, which is involved in tumor growth and aggressiveness in various cancers, including BC [100]. In transgenic mice specifically expressing Stat3 in bladder basal cells, a carcinogen, $N$-butyl- $N$-(4-hydroxybutyl)nitrosamine, highly induced bladder premalignant lesions and subsequent invasive BC [55]. BC cells derived from these mice contained a substantial number of $\mathrm{CK}_{14}{ }^{+}$cells, a stem cell marker, and possessed an increased ability to form spheres [55]. Hh signaling is involved in the regulation of stemness in BC [82]. In a murine chemical carcinogenesis model, the loss of Sonic Hh expression in carcinoma in situ subsequently reduced local concentrations of bone morphogenetic proteins (BMPs), which are urothelial differentiation factors. Reduced BMP levels promote tumor progression by allowing NMIBC to invade and grow (i.e., progression to MIBC) [82]. Cyclooxygenase-2 (COX-2) is overexpressed in BC compared with the normal urothelium [101], and its major bioproduct, prostaglandins (PGs), are involved in various biological process in BC, including inflammation and carcinogenesis [102]. Nuclear COX-2 is significantly associated with the upregulation of the stemness markers Oct $3 / 4$ and CD44v6, suggesting that COX-2 activation is involved in inflammation-mediated bladder CSC proliferation [60].

\subsubsection{Cancer Cell Dedifferentiation}

When airway tissue is damaged or lost, luminal secretory cells generate multipotent stem cells via dedifferentiation [103]. Dedifferentiation is a possible mechanism of glioblastoma CSC generation [104]. Pathological dedifferentiation is observed in clinical BC, especially in MIBC. Most BC is diagnosed as urothelial carcinoma; however, approximately $10 \%$ of urothelial carcinoma contains glandular differentiation, and up to $60 \%$ of urothelial carcinoma contains squamous differentiation $[105,106]$. Moreover, in rare cases, urothelial carcinoma cells can dedifferentiate into other variants, including sarcomatoid, lymphoepithelioma-like, and small cell carcinoma [107]. These pathological variants are usually aggressive and are associated with an unfavorable prognosis [108-110]. Interestingly, the gene expression profile of MIBC reveals that squamous or sarcomatoid differentiation is enriched in the basal-typed MIBC, which displays the CSC phenotype $[23,108]$.

\subsubsection{Cancer Cell Fusion}

Cell fusion may cause cellular transformation as well as cellular diversity, through drastic genotypic changes. Premature chromosome condensation (PCC) is a phenomenon observed when mitotic and interphase cells are fused, and PCC is frequently observed in various cancers, including BC $[111,112]$. Several mechanisms of cancer cell fusion have been proposed, but oncogenic viruses are the most likely candidate [113]. Human endogenous retroviruses (HERVs) may have oncogenic potential; they interfere with the anti-tumor immune system, promote cancer metastasis, upregulate the expression of oncogenes and growth factors, and inhibit tumor suppressors [114]. The HERV envelope glycoprotein HERVW-1 (also known as syncytin 1) is overexpressed in the placenta and plays an important role in the fusion of placental syncytiotrophoblasts. Additionally, HERVW-1 is overexpressed in certain cancers, such as breast and endometrial cancer [115]. HERVW-1 is reportedly overexpressed in $75.6 \%$ of $\mathrm{BC}$ tissues, whereas this glycoprotein is overexpressed in $6.1 \%$ of matched non-cancer tissues [116]. Interestingly, smoking, the most powerful epidemiological risk factor for bladder carcinogenesis, increases HERV transcription in the urothelium [117]. Apoptosis is another mechanism of cancer cell fusion [70]. The phagocytosis of apoptotic cancer cells may result in the transfer of oncogenes [118], thereby contributing to increased migratory capacity and metastatic potential [119]. Several studies have demonstrated that spontaneous cancer cell fusion promotes cancer aggressiveness and stemness; however, the mechanism of this phenomenon is unclear [120-122]. 
Cancer cell fusion results in nuclear reprogramming [123] and is suggested to be a putative mechanism of CSC generation [124]. The generation of bladder CSCs by cancer cell fusion has been suggested [24,125]. Cell fusion is an active biological process and requires fusogens, which are cell fusion proteins that are necessary for the fusion of the cell membrane. Interestingly, a bladder CSC marker, CD44, functions as a fusogen $[70,126]$. The partners for cell fusion with cancer cells may include various types of stem cells, macrophages [127], and BMDCs [128]. Based on the hypothesis of bladder CSC generation via cell fusion, homophilic (cancer cell to cancer cell) and heterophilic (cancer cell to non-cancer cell) fusion have been proposed (Figure 4).

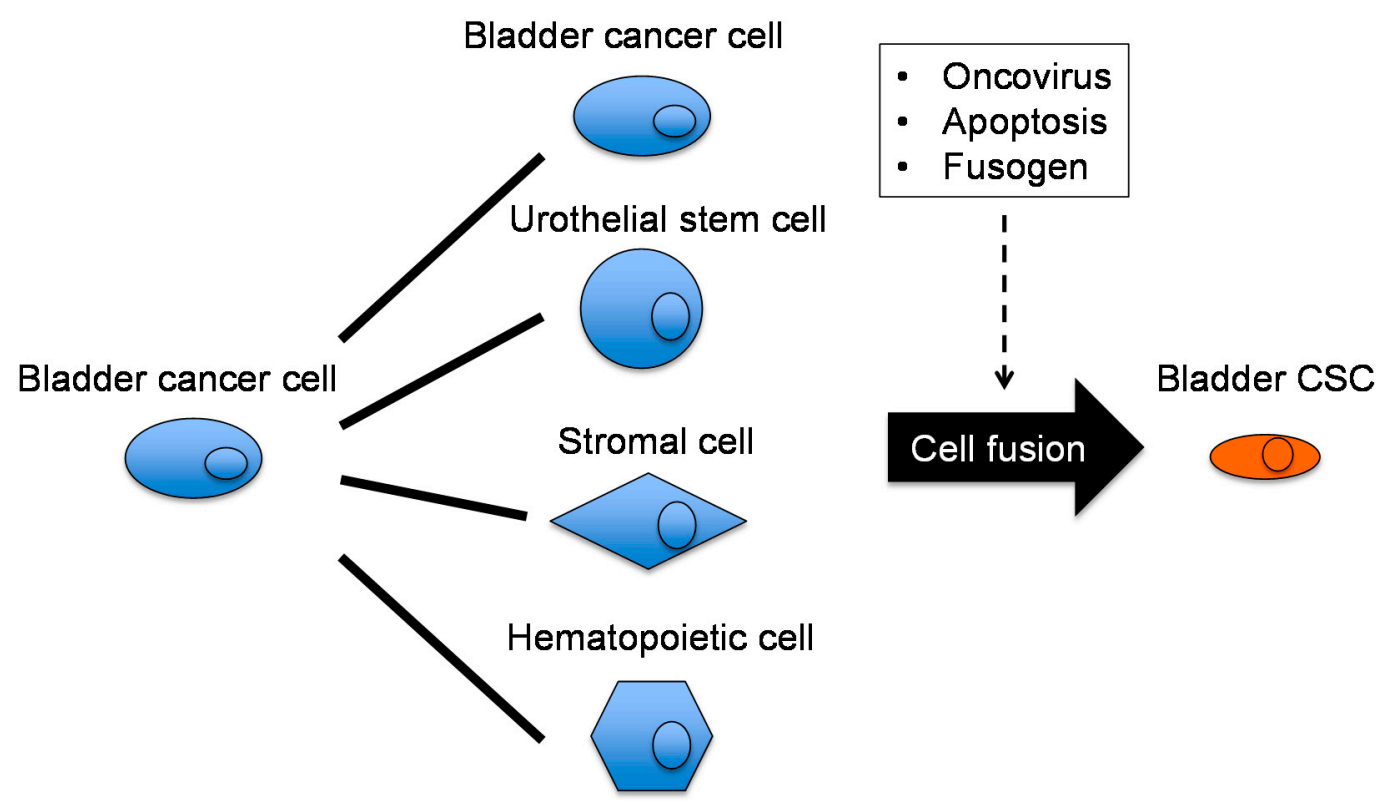

Figure 4. Hypothetical mechanism of cancer cell fusion for bladder CSC generation. Differentiated cancer cells may fuse with various cells, including homophilic fusion with BC cells and heterophilic fusion with urothelial stem cells, stromal cells, and hematopoietic cells. Cell fusion is triggered and driven by some oncoviruses, apoptosis, and fusogens.

\section{Possible Treatments for BC that Target Bladder CSCs}

MIBC frequently metastasizes to regional lymph nodes and distant organs. The current standard of care for distal or nodal metastases is cisplatin-based combination chemotherapy. Advanced disease initially exhibits a good response to treatment (an overall response rate of up to $70 \%$ ); however, most patients develop recurrences and eventually die from the disease [129]. According to the CSC theory, the majority of bladder non-CSCs initially die in response to systematic chemotherapy. However, a small population of bladder CSCs is spared, which results in tumor regrowth and clinical disease recurrence. Recently, several molecular targets for BC have been proposed (i.e., EGFR, FGFR, VEGFR, PI3K-Akt-mTOR, PD-1, COX-2, Aurora kinase A, and several miRNAs), and some chemical compounds are being investigated in clinical trials [130]. A treatment strategy that targets bladder CSCs would be rational and desirable but remains challenging to develop. Several potential therapeutic options for bladder CSCs are discussed below.

\subsection{Heat Shock Protein 90 (Hsp90) Inhibitors}

Hsp90 is a molecular chaperone that is required for the stability and function of numerous oncoproteins that are essential for certain cancer hallmarks, including apoptosis evasion and self-renewal [131]. Hsp90 inhibitors destabilize Hsp90 clients by dissociating Hsp90-Hsp90 client complexes, thereby promoting anti-tumor activity [131]. Hsp90 inhibitors can simultaneously block signaling from multiple oncogenes during the acquisition of therapeutic resistance and self-renewal 
capacity in glioma CSCs [132] and lymphoma CSCs [133]. Tatokoro et al., demonstrated that Hsp90 inhibitors potentially overcome the cisplatin-resistance of bladder CSCs in vitro and in vivo [59]. Bladder CSCs, a subpopulation of CD44 ${ }^{+} \mathrm{BC}$ cells, exhibited higher activity in the Akt and Erk signaling pathways compared with their $\mathrm{CD}_{4} 4^{-}$counterparts. An Hsp90 inhibitor, 17-DMAG, simultaneously inactivated both the Akt and Erk signaling pathways at non-cytotoxic concentrations and synergistically potentiated the cytotoxicity of cisplatin against bladder CSCs by enhancing apoptosis [59]. A potent Hsp90 inhibitor, ganetespib, is now being used in clinical trials and is expected to overcome the therapeutic resistance of CSCs in a wide variety of malignancies, including BC [134].

\subsection{Blocking Cyclooxygenase-2 (COX-2)-Prostaglandin-E2 (PGE2) Signaling}

Chemoresistance is a major challenge in the treatment of MIBC. During wound repair, normal stem cells are recruited from a quiescent pool at the wound site [135]. Similarly, bladder CSCs are mobilized to regrow in response to chemotherapy-induced damage, which contributes to the chemotherapy resistance of BC. Kurtova et al., found that chemotherapy releases PGE2 while effectively inducing apoptosis in human BC xenografts, which promotes CSC repopulation and tumor regrowth between chemotherapy cycles [136]. A PGE2-neutralizing antibody and the COX-2 inhibitor celecoxib, which inhibits PGE2 production, abrogate CSC repopulation during chemotherapy intervals and effectively attenuate the progressive manifestation of chemoresistance [136].

\subsection{Blockade of $C D 47$}

Intravesical instillation of bacillus Calmette-Guerin (BCG) has long been the standard of care for high-risk NMIBC, whereas its effectiveness against MIBC is limited. Macrophages play a key role in antigen presentation to T-cells via phagocytosis to elicit an anti-tumor immune response [137]. Recent clinical studies have demonstrated that immune checkpoint inhibition, which restores anti-tumor T-cell immunity, is associated with a beneficial objective response and remarkably improves the prognosis of patients with advanced malignancies, including patients with BC [138]. Chan et al. reported another potential type of immunotherapy against BC, where bladder CSCs express higher levels of CD47, a cell surface protein that provides an inhibitory signal for macrophage phagocytosis, compared with the rest of the tumor $[20,139]$. Blockade of CD47 with a monoclonal antibody resulted in macrophage engulfment of $\mathrm{BC}$ cells in vitro, suggesting that immunotherapy against $\mathrm{CD} 47$ could be effective in the treatment of MIBC.

\subsection{Telomerase Inhibitors}

Telomerase activity is up-regulated in $85 \%$ to $90 \%$ of cancers [140]. Telomerase is activated in a vast majority of tumor cells and in CSCs [141], and the telomere length of CSCs is shorter than that of the majority of tumor cells [142,143]. The enforced elongation of the telomere length of cancer cells induces cellular differentiation, which suggests that telomere length is related to cancer cell differentiation [144]. Of particular note is that CSCs are suggested to be sensitive to telomerase-based therapy [145]. TERT promoter mutations and subsequent telomerase reactivation is often observed in BC [146]. The C228T mutation of the TERT promoter frequently occurs in bladder CSCs, which contributes to tumorigenesis [147]. Although not specifically in bladder CSCs, the telomerase inhibitor GRN163L induces growth arrest in T24 BC cells but not in normal urothelial cells [148]. Furthermore, antisense oligodeoxynucleotides against the telomerase enzyme hTERT reduced the growth of BC cells [149]. These findings suggest that telomerase inhibitors may be promising agents for bladder CSCs.

\subsection{Retinoids}

Retinoids are signaling molecules that regulate cellular events, such as development, differentiation, proliferation, and apoptosis, by binding to RAR/RXR receptors, which initiates a cascade of changes in the structure of chromatin [150]. Retinoids have been shown to regulate 
self-renewal and pluripotency in ES and progenitor cells [151] and to promote differentiation and initiate stable epigenetic changes in CSCs [152]. All-trans retinoic acid (ATRA) is a powerful antineoplastic agent for human acute promyelocytic leukemia (APL) [153]. ATRA exerts anti-tumor effects on glioma CSCs [154] and lung CSCs [155] via differentiation and a reversion to heterogeneity. In addition, retinoid signaling is involved in the specification and regeneration of urothelial progenitor basal cells [156]. In BC, retinoic acid inhibits both VEGF and EGF signaling, thereby reducing the recurrence rate and improving the prognosis of NMIBC patients [157].

\subsection{Other Putative Strategies for Targeting Bladder CSCS}

CSCs use the same signaling pathway as ES cells. Therefore, the Wnt, Notch, and Hh pathways are emerging as therapeutic targets for CSCs [158]. Wnt signaling is activated and contributes to cancer progression in BC $[49,159]$; however, the therapeutic efficacy of Wnt signaling inhibition in bladder CSCs is not well studied. The G protein-coupled receptor smoothened (SMO) is a downstream effector of the Hh pathway, and the selective SMO antagonist LDE225 is now being studied in clinical trials of BC [130]. Reportedly, TGF- $\beta$ signaling maintains the cancer stemness of glioma cells by up-regulating SOX2 [160]. Plasma TGF- $\beta 1$ levels are elevated in patients with MIBC [161], and a TGF- $\beta$ receptor inhibitor attenuates the invasive potential of BC cells [162], which suggests that inhibition of TGF- $\beta$ signaling may be effective in abrogating the stemness of BC. However, TGF- $\beta$ initially inhibits epithelial growth [163]; therefore, TGF- $\beta$ inhibitors should be used with caution in cancer patients. B-cell-specific Moloney murine leukemia virus insertion site 1 (Bmi1) plays a role in self-renewal and differentiation in both normal stem cells and CSCs. A small molecule inhibitor for Bmi1, PTC-209, inhibits tumor growth in colon cancer xenografts with long-term and irreversible effects [164]. In bladder CSCs, Bmi1 knockdown impairs cell proliferation, migration, and sphere formation, and enhances the sensitivity of cells to cisplatin treatment [165].

\section{Future Perspectives on Bladder CSC Research}

The CSC theory was first established in human blood malignancies as a model for normal hematopoiesis and has since been progressively applied to many solid tumors. Cultured cancer cell lines derived from solid tumors in patients and genetically engineered mice have increased our understanding of CSC cancer biology; however, traditional CSC models have not predicted clinical success [5]. Several questions and controversies regarding CSCs in solid tumors need to be addressed. Most cancer cell lines derived from heterogeneous solid tumors are selected for plastic culture systems with a nutrition and oxygen-rich environment; however, the xenograft tumors used to define CSCs exhibit cellular homogeneity and do not mimic solid tumors with tumor heterogeneity. This finding suggests that established cancer cell lines predominantly or exclusively have self-renewal potential rather than differentiation potential, which indicates that they may be almost identical to CSCs without isolation. Therefore, isolated cells that express various markers may be highly reproducible or self-renewing cancer cells. Another concern is that CSCs in solid tumors are usually isolated after dissociation into single cells; however, in contrast to blood malignancies, tumorigenicity requires cell-cell or cell-matrix attachment by cancer cells and an assembly of stromal cells, such as endothelial cells, fibroblasts, and inflammatory cells. The hypotheses on the origin of CSCs, the underlying mechanism of CSC generation, and the existence of CSCs in solid tumors in the human body are inconsistent and inconclusive. However we may already have clues to answer these questions, because we have repeatedly observed a small number of living tumor cells as well as remarkable tumor shrinkage, by antineoplastic agents in in vivo experiments and in clinical trials.

In the 21st century, most types of cancer, including BC, are still incurable when they metastasize. The hypothesis of bladder CSCs is strongly supported by recent studies; however, we have not yet obtained conclusive evidence of the existence of bladder CSCs in the clinical setting. It is urgent that we identify specific markers for bladder CSCs and demonstrate both the pluripotency and self-renewal potential of bladder CSCs derived from clinical samples. As described in this review, bladder CSCs 
may be generated and maintained by more dynamic biological processes than initially expected. Bladder CSCs may inevitably emerge in the residual tumor via an unknown dynamic mechanism. Accumulating evidence of cancer cell plasticity suggests that therapies targeting either bladder CSCs or bladder non-CSCs are not sufficient to achieve complete recovery. A plausible and attractive strategy may be to regain the organizing ability of the $\mathrm{BC}$ cells and shift them to a normal differentiation process. We believe that a better understanding of bladder CSC biology may improve the therapeutic outcomes of $\mathrm{BC}$ in the near future.

Acknowledgments: This work was supported in part by the Japan Society for the Promotion of Science (JSPS) KAKENHI, grant number 15K06891 (Toshiro Migita).

Author Contributions: Tomokazu Ohishi, Fumitaka Koga, and Toshiro Migita contributed equally to this work.

Conflicts of Interest: The authors declare no conflict of interest.

\section{References}

1. Fialkow, P.J.; Jacobson, R.J.; Papayannopoulou, T. Chronic myelocytic leukemia: Clonal origin in a stem cell common to the granulocyte, erythrocyte, platelet and monocyte/macrophage. Am. J. Med. 1977, 63, 125-130. [CrossRef]

2. Bonnet, D.; Dick, J.E. Human acute myeloid leukemia is organized as a hierarchy that originates from a primitive hematopoietic cell. Nat. Med. 1997, 3, 730-737. [CrossRef] [PubMed]

3. Clarke, M.F.; Dick, J.E.; Dirks, P.B.; Eaves, C.J.; Jamieson, C.H.; Jones, D.L.; Visvader, J.; Weissman, I.L.; Wahl, G.M. Cancer stem cells-Perspectives on current status and future directions: AACR Workshop on cancer stem cells. Cancer Res. 2006, 66, 9339-9344. [CrossRef] [PubMed]

4. Kelly, P.N.; Dakic, A.; Adams, J.M.; Nutt, S.L.; Strasser, A. Tumor growth need not be driven by rare cancer stem cells. Science 2007, 317. [CrossRef] [PubMed]

5. Williams, S.A.; Anderson, W.C.; Santaguida, M.T.; Dylla, S.J. Patient-derived xenografts, the cancer stem cell paradigm, and cancer pathobiology in the 21st century. Lab. Investig. J. Tech. Methods Pathol. 2013, 93, 970-982. [CrossRef] [PubMed]

6. Al-Hajj, M.; Wicha, M.S.; Benito-Hernandez, A.; Morrison, S.J.; Clarke, M.F. Prospective identification of tumorigenic breast cancer cells. Proc. Natl. Acad. Sci. USA 2003, 100, 3983-3988. [CrossRef] [PubMed]

7. Singh, S.K.; Clarke, I.D.; Terasaki, M.; Bonn, V.E.; Hawkins, C.; Squire, J.; Dirks, P.B. Identification of a cancer stem cell in human brain tumors. Cancer Res. 2003, 63, 5821-5828. [PubMed]

8. Ricci-Vitiani, L.; Lombardi, D.G.; Pilozzi, E.; Biffoni, M.; Todaro, M.; Peschle, C.; de Maria, R. Identification and expansion of human colon-cancer-initiating cells. Nature 2007, 445, 111-115. [CrossRef] [PubMed]

9. O'Brien, C.A.; Pollett, A.; Gallinger, S.; Dick, J.E. A human colon cancer cell capable of initiating tumour growth in immunodeficient mice. Nature 2007, 445, 106-110. [CrossRef] [PubMed]

10. Dalerba, P.; Dylla, S.J.; Park, I.K.; Liu, R.; Wang, X.; Cho, R.W.; Hoey, T.; Gurney, A.; Huang, E.H.; Simeone, D.M.; et al. Phenotypic characterization of human colorectal cancer stem cells. Proc. Natl. Acad. Sci. USA 2007, 104, 10158-10163. [CrossRef] [PubMed]

11. Prince, M.E.; Sivanandan, R.; Kaczorowski, A.; Wolf, G.T.; Kaplan, M.J.; Dalerba, P.; Weissman, I.L.; Clarke, M.F.; Ailles, L.E. Identification of a subpopulation of cells with cancer stem cell properties in head and neck squamous cell carcinoma. Proc. Natl. Acad. Sci. USA 2007, 104, 973-978. [CrossRef] [PubMed]

12. Li, C.; Heidt, D.G.; Dalerba, P.; Burant, C.F.; Zhang, L.; Adsay, V.; Wicha, M.; Clarke, M.F.; Simeone, D.M. Identification of pancreatic cancer stem cells. Cancer Res. 2007, 67, 1030-1037. [CrossRef] [PubMed]

13. Patrawala, L.; Calhoun, T.; Schneider-Broussard, R.; Li, H.; Bhatia, B.; Tang, S.; Reilly, J.G.; Chandra, D.; Zhou, J.; Claypool, K.; et al. Highly purified $\mathrm{CD} 44^{+}$prostate cancer cells from xenograft human tumors are enriched in tumorigenic and metastatic progenitor cells. Oncogene 2006, 25, 1696-1708. [CrossRef] [PubMed]

14. Schatton, T.; Murphy, G.F.; Frank, N.Y.; Yamaura, K.; Waaga-Gasser, A.M.; Gasser, M.; Zhan, Q.; Jordan, S.; Duncan, L.M.; Weishaupt, C.; et al. Identification of cells initiating human melanomas. Nature 2008, 451, 345-349. [CrossRef] [PubMed]

15. Ferlay, J.; Soerjomataram, I.; Dikshit, R.; Eser, S.; Mathers, C.; Rebelo, M.; Parkin, D.M.; Forman, D.; Bray, F. Cancer incidence and mortality worldwide: Sources, methods and major patterns in GLOBOCAN 2012. Int. J. Cancer 2015, 136, E359-E386. [CrossRef] [PubMed] 
16. Apodaca, G. The uroepithelium: Not just a passive barrier. Traffic 2004, 5, 117-128. [CrossRef] [PubMed]

17. Khandelwal, P.; Abraham, S.N.; Apodaca, G. Cell biology and physiology of the uroepithelium. Am. J. Physiol. Ren. Physiol. 2009, 297, F1477-F1501. [CrossRef] [PubMed]

18. Ward, G.K.; Stewart, S.S.; Price, G.B.; Mackillop, W.J. Cellular heterogeneity in normal human urothelium: An analysis of optical properties and lectin binding. J. Histochem. Cytochem. 1986, 34, 841-846. [CrossRef] [PubMed]

19. Kurzrock, E.A.; Lieu, D.K.; Degraffenried, L.A.; Chan, C.W.; Isseroff, R.R. Label-retaining cells of the bladder: Candidate urothelial stem cells. Am. J. Physiol. Ren. Physiol. 2008, 294, F1415-F1421. [CrossRef] [PubMed]

20. Chan, K.S.; Espinosa, I.; Chao, M.; Wong, D.; Ailles, L.; Diehn, M.; Gill, H.; Presti, J., Jr.; Chang, H.Y.; van de Rijn, M.; et al. Identification, molecular characterization, clinical prognosis, and therapeutic targeting of human bladder tumor-initiating cells. Proc. Natl. Acad. Sci. USA 2009, 106, 14016-14021. [CrossRef] [PubMed]

21. Tran, M.N.; Goodwin Jinesh, G.; McConkey, D.J.; Kamat, A.M. Bladder cancer stem cells. Curr. Stem Cell Res. Ther. 2010, 5, 387-395. [CrossRef] [PubMed]

22. Ho, P.L.; Kurtova, A.; Chan, K.S. Normal and neoplastic urothelial stem cells: Getting to the root of the problem. Nat. Rev. Urol. 2012, 9, 583-594. [CrossRef] [PubMed]

23. Knowles, M.A.; Hurst, C.D. Molecular biology of bladder cancer: New insights into pathogenesis and clinical diversity. Nat. Rev. Cancer 2015, 15, 25-41. [CrossRef] [PubMed]

24. Goodwin Jinesh, G.; Willis, D.L.; Kamat, A.M. Bladder cancer stem cells: Biological and therapeutic perspectives. Curr. Stem Cell Res. Ther. 2014, 9, 89-101. [PubMed]

25. Van der Horst, G.; Bos, L.; van der Pluijm, G. Epithelial plasticity, cancer stem cells, and the tumor-supportive stroma in bladder carcinoma. Mol. Cancer Res. MCR 2012, 10, 995-1009. [CrossRef] [PubMed]

26. Brandt, W.D.; Matsui, W.; Rosenberg, J.E.; He, X.; Ling, S.; Schaeffer, E.M.; Berman, D.M. Urothelial carcinoma: Stem cells on the edge. Cancer Metastasis Rev. 2009, 28, 291-304. [CrossRef] [PubMed]

27. Bryan, R.T. Bladder cancer and cancer stem cells: Basic science and implications for therapy. Sci. World J. 2011, 11, 1187-1194. [CrossRef] [PubMed]

28. Gerlinger, M.; Rowan, A.J.; Horswell, S.; Larkin, J.; Endesfelder, D.; Gronroos, E.; Martinez, P.; Matthews, N.; Stewart, A.; Tarpey, P.; et al. Intratumor heterogeneity and branched evolution revealed by multiregion sequencing. N. Engl. J. Med. 2012, 366, 883-892. [CrossRef] [PubMed]

29. Carter, S.L.; Eklund, A.C.; Kohane, I.S.; Harris, L.N.; Szallasi, Z. A signature of chromosomal instability inferred from gene expression profiles predicts clinical outcome in multiple human cancers. Nat. Genet. 2006, 38, 1043-1048. [CrossRef] [PubMed]

30. Chin, K.; DeVries, S.; Fridlyand, J.; Spellman, P.T.; Roydasgupta, R.; Kuo, W.L.; Lapuk, A.; Neve, R.M.; Qian, Z.; Ryder, T.; et al. Genomic and transcriptional aberrations linked to breast cancer pathophysiologies. Cancer Cell 2006, 10, 529-541. [CrossRef] [PubMed]

31. Vaupel, P.; Kallinowski, F.; Okunieff, P. Blood flow, oxygen and nutrient supply, and metabolic microenvironment of human tumors: A review. Cancer Res. 1989, 49, 6449-6465. [PubMed]

32. Freitas, I.; Baronzio, G.F. Tumor hypoxia, reoxygenation and oxygenation strategies: Possible role in photodynamic therapy. J. Photochem. Photobiol. B 1991, 11, 3-30. [CrossRef]

33. Baccelli, I.; Trumpp, A. The evolving concept of cancer and metastasis stem cells. J. Cell Biol. 2012, 198, 281-293. [CrossRef] [PubMed]

34. Kreso, A.; Dick, J.E. Evolution of the cancer stem cell model. Cell Stem Cell 2014, 14, 275-291. [CrossRef] [PubMed]

35. Nguyen, L.V.; Vanner, R.; Dirks, P.; Eaves, C.J. Cancer stem cells: An evolving concept. Nat. Rev. Cancer 2012, 12, 133-143. [CrossRef] [PubMed]

36. Beck, B.; Blanpain, C. Unravelling cancer stem cell potential. Nat. Rev. Cancer 2013, 13, 727-738. [CrossRef] [PubMed]

37. Holohan, C.; van Schaeybroeck, S.; Longley, D.B.; Johnston, P.G. Cancer drug resistance: An evolving paradigm. Nat. Rev. Cancer 2013, 13, 714-726. [CrossRef] [PubMed]

38. Shervington, A.; Lu, C. Expression of multidrug resistance genes in normal and cancer stem cells. Cancer Investig. 2008, 26, 535-542. [CrossRef] [PubMed]

39. Quintana, E.; Shackleton, M.; Sabel, M.S.; Fullen, D.R.; Johnson, T.M.; Morrison, S.J. Efficient tumour formation by single human melanoma cells. Nature 2008, 456, 593-598. [CrossRef] [PubMed] 
40. Hanahan, D.; Weinberg, R.A. The hallmarks of cancer. Cell 2000, 100, 57-70. [CrossRef]

41. Dalerba, P.; Cho, R.W.; Clarke, M.F. Cancer stem cells: Models and concepts. Annu. Rev. Med. 2007, 58, 267-284. [CrossRef] [PubMed]

42. Shin, K.; Lee, J.; Guo, N.; Kim, J.; Lim, A.; Qu, L.; Mysorekar, I.U.; Beachy, P.A. Hedgehog/Wnt feedback supports regenerative proliferation of epithelial stem cells in bladder. Nature 2011, 472, 110-114. [CrossRef] [PubMed]

43. Qin, D.; Long, T.; Deng, J.; Zhang, Y. Urine-derived stem cells for potential use in bladder repair. Stem Cell Res. Ther. 2014, 5. [CrossRef] [PubMed]

44. Gaisa, N.T.; Graham, T.A.; McDonald, S.A.; Canadillas-Lopez, S.; Poulsom, R.; Heidenreich, A.; Jakse, G.; Tadrous, P.J.; Knuechel, R.; Wright, N.A. The human urothelium consists of multiple clonal units, each maintained by a stem cell. J. Pathol. 2011, 225, 163-171. [CrossRef] [PubMed]

45. Wu, X.R. Urothelial tumorigenesis: A tale of divergent pathways. Nat. Rev. Cancer 2005, 5, 713-725. [CrossRef] [PubMed]

46. McConkey, D.J.; Lee, S.; Choi, W.; Tran, M.; Majewski, T.; Lee, S.; Siefker-Radtke, A.; Dinney, C.; Czerniak, B. Molecular genetics of bladder cancer: Emerging mechanisms of tumor initiation and progression. Urol. Oncol. 2010, 28, 429-440. [CrossRef] [PubMed]

47. Billerey, C.; Chopin, D.; Aubriot-Lorton, M.H.; Ricol, D.; Gil Diez de Medina, S.; van Rhijn, B.; Bralet, M.P.; Lefrere-Belda, M.A.; Lahaye, J.B.; Abbou, C.C.; et al. Frequent FGFR3 mutations in papillary non-invasive bladder (pTa) tumors. Am. J. Pathol. 2001, 158, 1955-1959. [CrossRef]

48. Hepburn, A.C.; Veeratterapillay, R.; Williamson, S.C.; El-Sherif, A.; Sahay, N.; Thomas, H.D.; Mantilla, A.; Pickard, R.S.; Robson, C.N.; Heer, R. Side population in human non-muscle invasive bladder cancer enriches for cancer stem cells that are maintained by MAPK signalling. PLoS ONE 2012, 7, e50690. [CrossRef] [PubMed]

49. He, X.; Marchionni, L.; Hansel, D.E.; Yu, W.; Sood, A.; Yang, J.; Parmigiani, G.; Matsui, W.; Berman, D.M. Differentiation of a highly tumorigenic basal cell compartment in urothelial carcinoma. Stem Cells 2009, 27, 1487-1495. [CrossRef] [PubMed]

50. Ning, Z.F.; Huang, Y.J.; Lin, T.X.; Zhou, Y.X.; Jiang, C.; Xu, K.W.; Huang, H.; Yin, X.B.; Huang, J. Subpopulations of stem-like cells in side population cells from the human bladder transitional cell cancer cell line T24. J. Int. Med. Res. 2009, 37, 621-630. [CrossRef] [PubMed]

51. She, J.J.; Zhang, P.G.; Wang, Z.M.; Gan, W.M.; Che, X.M. Identification of side population cells from bladder cancer cells by DyeCycle Violet staining. Cancer Biol. Ther. 2008, 7, 1663-1668. [CrossRef] [PubMed]

52. Su, Y.; Qiu, Q.; Zhang, X.; Jiang, Z.; Leng, Q.; Liu, Z.; Stass, S.A.; Jiang, F. Aldehyde dehydrogenase 1 A1-positive cell population is enriched in tumor-initiating cells and associated with progression of bladder cancer. Epidemiol. Biomark. Prev. 2010, 19, 327-337. [CrossRef] [PubMed]

53. Yang, Y.M.; Chang, J.W. Bladder cancer initiating cells (BCICs) are among EMA-CD44v6 ${ }^{+}$subset: Novel methods for isolating undetermined cancer stem (initiating) cells. Cancer Investig. 2008, 26, 725-733. [CrossRef] [PubMed]

54. Falso, M.J.; Buchholz, B.A.; White, R.W. Stem-like cells in bladder cancer cell lines with differential sensitivity to cisplatin. Anticancer Res. 2012, 32, 733-738. [PubMed]

55. Ho, P.L.; Lay, E.J.; Jian, W.; Parra, D.; Chan, K.S. Stat3 activation in urothelial stem cells leads to direct progression to invasive bladder cancer. Cancer Res. 2012, 72, 3135-3142. [CrossRef] [PubMed]

56. Zhang, Y.; Wang, Z.; Yu, J.; Shi, J.; Wang, C.; Fu, W.; Chen, Z.; Yang, J. Cancer stem-like cells contribute to cisplatin resistance and progression in bladder cancer. Cancer Lett. 2012, 322, 70-77. [CrossRef] [PubMed]

57. Takaishi, S.; Okumura, T.; Tu, S.; Wang, S.S.; Shibata, W.; Vigneshwaran, R.; Gordon, S.A.; Shimada, Y.; Wang, T.C. Identification of gastric cancer stem cells using the cell surface marker CD44. Stem Cells 2009, 27, 1006-1020. [CrossRef] [PubMed]

58. Collins, A.T.; Berry, P.A.; Hyde, C.; Stower, M.J.; Maitland, N.J. Prospective identification of tumorigenic prostate cancer stem cells. Cancer Res. 2005, 65, 10946-10951. [CrossRef] [PubMed]

59. Tatokoro, M.; Koga, F.; Yoshida, S.; Kawakami, S.; Fujii, Y.; Neckers, L.; Kihara, K. Potential role of Hsp90 inhibitors in overcoming cisplatin resistance of bladder cancer-initiating cells. Int. J. Cancer J. Int. Cancer 2012, 131, 987-996. [CrossRef] [PubMed] 
60. Thanan, R.; Murata, M.; Ma, N.; Hammam, O.; Wishahi, M.; El Leithy, T.; Hiraku, Y.; Oikawa, S.; Kawanishi, S. Nuclear localization of COX-2 in relation to the expression of stemness markers in urinary bladder cancer. Mediators Inflamm. 2012, 2012. [CrossRef] [PubMed]

61. Huang, P.; Watanabe, M.; Kaku, H.; Ueki, H.; Noguchi, H.; Sugimoto, M.; Hirata, T.; Yamada, H.; Takei, K.; Zheng, S.; et al. Cancer stem cell-like characteristics of a CD133 subpopulation in the J82 human bladder cancer cell line. Mol. Clin. Oncol. 2013, 1, 180-184. [PubMed]

62. Bentivegna, A.; Conconi, D.; Panzeri, E.; Sala, E.; Bovo, G.; Vigano, P.; Brunelli, S.; Bossi, M.; Tredici, G.; Strada, G.; et al. Biological heterogeneity of putative bladder cancer stem-like cell populations from human bladder transitional cell carcinoma samples. Cancer Sci. 2010, 101, 416-424. [CrossRef] [PubMed]

63. Peek, E.M.; Li, D.R.; Zhang, H.; Kim, H.P.; Zhang, B.; Garraway, I.P.; Chin, A.I. Stromal modulation of bladder cancer-initiating cells in a subcutaneous tumor model. Am. J. Cancer Res. 2012, 2, 745-751. [PubMed]

64. Volkmer, J.P.; Sahoo, D.; Chin, R.K.; Ho, P.L.; Tang, C.; Kurtova, A.V.; Willingham, S.B.; Pazhanisamy, S.K.; Contreras-Trujillo, H.; Storm, T.A.; et al. Three differentiation states risk-stratify bladder cancer into distinct subtypes. Proc. Natl. Acad. Sci. USA 2012, 109, 2078-2083. [CrossRef] [PubMed]

65. Nagata, S.; Hirano, K.; Kanemori, M.; Sun, L.T.; Tada, T. Self-renewal and pluripotency acquired through somatic reprogramming to human cancer stem cells. PLoS ONE 2012, 7, e48699. [CrossRef] [PubMed]

66. Ohnishi, K.; Semi, K.; Yamamoto, T.; Shimizu, M.; Tanaka, A.; Mitsunaga, K.; Okita, K.; Osafune, K.; Arioka, Y.; Maeda, T.; et al. Premature termination of reprogramming in vivo leads to cancer development through altered epigenetic regulation. Cell 2014, 156, 663-677. [CrossRef] [PubMed]

67. Sell, S.; Pierce, G.B. Maturation arrest of stem cell differentiation is a common pathway for the cellular origin of teratocarcinomas and epithelial cancers. Lab. Investig. J. Tech. Methods Pathol. 1994, 70, 6-22.

68. Takahashi, K.; Yamanaka, S. Induction of pluripotent stem cells from mouse embryonic and adult fibroblast cultures by defined factors. Cell 2006, 126, 663-676. [CrossRef] [PubMed]

69. Pan, Q.; Fouraschen, S.M.; de Ruiter, P.E.; Dinjens, W.N.; Kwekkeboom, J.; Tilanus, H.W.; van der Laan, L.J. Detection of spontaneous tumorigenic transformation during culture expansion of human mesenchymal stromal cells. Exp. Biol. Med. 2014, 239, 105-115. [CrossRef] [PubMed]

70. Bjerkvig, R.; Tysnes, B.B.; Aboody, K.S.; Najbauer, J.; Terzis, A.J. Opinion: The origin of the cancer stem cell: Current controversies and new insights. Nat. Rev. Cancer 2005, 5, 899-904. [CrossRef] [PubMed]

71. Bachoo, R.M.; Maher, E.A.; Ligon, K.L.; Sharpless, N.E.; Chan, S.S.; You, M.J.; Tang, Y.; DeFrances, J.; Stover, E.; Weissleder, R.; et al. Epidermal growth factor receptor and Ink4a/Arf: Convergent mechanisms governing terminal differentiation and transformation along the neural stem cell to astrocyte axis. Cancer Cell 2002, 1, 269-277. [CrossRef]

72. Chaffer, C.L.; Brueckmann, I.; Scheel, C.; Kaestli, A.J.; Wiggins, P.A.; Rodrigues, L.O.; Brooks, M.; Reinhardt, F.; $\mathrm{Su}, \mathrm{Y}$; Polyak, K.; et al. Normal and neoplastic nonstem cells can spontaneously convert to a stem-like state. Proc. Natl. Acad. Sci. USA 2011, 108, 7950-7955. [CrossRef] [PubMed]

73. Scaffidi, P.; Misteli, T. In vitro generation of human cells with cancer stem cell properties. Nat. Cell Biol. 2011, 13, 1051-1061. [CrossRef] [PubMed]

74. Oshima, N.; Yamada, Y.; Nagayama, S.; Kawada, K.; Hasegawa, S.; Okabe, H.; Sakai, Y.; Aoi, T. Induction of cancer stem cell properties in colon cancer cells by defined factors. PLoS ONE 2014, 9, e101735. [CrossRef] [PubMed]

75. Van Batavia, J.; Yamany, T.; Molotkov, A.; Dan, H.; Mansukhani, M.; Batourina, E.; Schneider, K.; Oyon, D.; Dunlop, M.; Wu, X.R.; et al. Bladder cancers arise from distinct urothelial sub-populations. Nat. Cell Biol. 2014, 16, 982-991. [CrossRef] [PubMed]

76. Choi, W.; Czerniak, B.; Ochoa, A.; Su, X.; Siefker-Radtke, A.; Dinney, C.; McConkey, D.J. Intrinsic basal and luminal subtypes of muscle-invasive bladder cancer. Nat. Rev. Urol. 2014, 11, 400-410. [CrossRef] [PubMed]

77. Barker, N.; Ridgway, R.A.; van Es, J.H.; van de Wetering, M.; Begthel, H.; van den Born, M.; Danenberg, E.; Clarke, A.R.; Sansom, O.J.; Clevers, H. Crypt stem cells as the cells-of-origin of intestinal cancer. Nature 2009, 457, 608-611. [CrossRef] [PubMed]

78. Shin, K.; Lim, A.; Odegaard, J.I.; Honeycutt, J.D.; Kawano, S.; Hsieh, M.H.; Beachy, P.A. Cellular origin of bladder neoplasia and tissue dynamics of its progression to invasive carcinoma. Nat. Cell Biol. 2014, 16, 469-478. [CrossRef] [PubMed] 
79. Houghton, J.; Stoicov, C.; Nomura, S.; Rogers, A.B.; Carlson, J.; Li, H.; Cai, X.; Fox, J.G.; Goldenring, J.R.; Wang, T.C. Gastric cancer originating from bone marrow-derived cells. Science 2004, 306, 1568-1571. [CrossRef] [PubMed]

80. Lin, H.; Hu, L.; Chen, L.; Yu, H.; Wang, Q.; Chen, P.; Hu, X.T.; Cai, X.J.; Guan, X.Y. Chemically-induced cancers do not originate from bone marrow-derived cells. PLoS ONE 2012, 7, e30493. [CrossRef] [PubMed]

81. Damrauer, J.S.; Hoadley, K.A.; Chism, D.D.; Fan, C.; Tiganelli, C.J.; Wobker, S.E.; Yeh, J.J.; Milowsky, M.I.; Iyer, G.; Parker, J.S.; et al. Intrinsic subtypes of high-grade bladder cancer reflect the hallmarks of breast cancer biology. Proc. Natl. Acad. Sci. USA 2014, 111, 3110-3115. [CrossRef] [PubMed]

82. Shin, K.; Lim, A.; Zhao, C.; Sahoo, D.; Pan, Y.; Spiekerkoetter, E.; Liao, J.C.; Beachy, P.A. Hedgehog signaling restrains bladder cancer progression by eliciting stromal production of urothelial differentiation factors. Cancer Cell 2014, 26, 521-533. [CrossRef] [PubMed]

83. Zhao, Y.; Bao, Q.; Renner, A.; Camaj, P.; Eichhorn, M.; Ischenko, I.; Angele, M.; Kleespies, A.; Jauch, K.W.; Bruns, C. Cancer stem cells and angiogenesis. Int. J. Dev. Biol. 2011, 55, 477-482. [CrossRef] [PubMed]

84. Baumgart, E.; Cohen, M.S.; Silva Neto, B.; Jacobs, M.A.; Wotkowicz, C.; Rieger-Christ, K.M.; Biolo, A.; Zeheb, R.; Loda, M.; Libertino, J.A.; et al. Identification and prognostic significance of an epithelial-mesenchymal transition expression profile in human bladder tumors. Clin. Cancer Res. 2007, 13, 1685-1694. [CrossRef] [PubMed]

85. Mani, S.A.; Guo, W.; Liao, M.J.; Eaton, E.N.; Ayyanan, A.; Zhou, A.Y.; Brooks, M.; Reinhard, F.; Zhang, C.C.; Shipitsin, M.; et al. The epithelial-mesenchymal transition generates cells with properties of stem cells. Cell 2008, 133, 704-715. [CrossRef] [PubMed]

86. Battula, V.L.; Evans, K.W.; Hollier, B.G.; Shi, Y.; Marini, F.C.; Ayyanan, A.; Wang, R.Y.; Brisken, C.; Guerra, R.; Andreeff, M.; et al. Epithelial-mesenchymal transition-derived cells exhibit multilineage differentiation potential similar to mesenchymal stem cells. Stem Cells 2010, 28, 1435-1445. [CrossRef] [PubMed]

87. Wei, H.; Kamat, A.M.; Aldousari, S.; Ye, Y.; Huang, M.; Dinney, C.P.; Wu, X. Genetic variations in the transforming growth factor $\beta$ pathway as predictors of bladder cancer risk. PLoS ONE 2012, 7, e51758. [CrossRef] [PubMed]

88. Fan, Y.; Shen, B.; Tan, M.; Mu, X.; Qin, Y.; Zhang, F.; Liu, Y. TGF- $\beta$-induced upregulation of malat1 promotes bladder cancer metastasis by associating with suz12. Clin. Cancer Res. 2014, 20, 1531-1541. [CrossRef] [PubMed]

89. Hung, T.T.; Wang, H.; Kingsley, E.A.; Risbridger, G.P.; Russell, P.J. Molecular profiling of bladder cancer: Involvement of the TGF- $\beta$ pathway in bladder cancer progression. Cancer Lett. 2008, 265, 27-38. [CrossRef] [PubMed]

90. Xing, F.; Okuda, H.; Watabe, M.; Kobayashi, A.; Pai, S.K.; Liu, W.; Pandey, P.R.; Fukuda, K.; Hirota, S.; Sugai, T.; et al. Hypoxia-induced Jagged2 promotes breast cancer metastasis and self-renewal of cancer stem-like cells. Oncogene 2011, 30, 4075-4086. [CrossRef] [PubMed]

91. Koga, F.; Kageyama, Y.; Kawakami, S.; Fujii, Y.; Hyochi, N.; Ando, N.; Takizawa, T.; Saito, K.; Iwai, A.; Masuda, H.; et al. Prognostic significance of endothelial Per-Arnt-sim domain protein 1/hypoxia-inducible factor- $2 \alpha$ expression in a subset of tumor associated macrophages in invasive bladder cancer. J. Urol. 2004, 171, 1080-1084. [CrossRef] [PubMed]

92. Lagos-Quintana, M.; Rauhut, R.; Lendeckel, W.; Tuschl, T. Identification of novel genes coding for small expressed RNAs. Science 2001, 294, 853-858. [CrossRef] [PubMed]

93. Huang, J.C.; Babak, T.; Corson, T.W.; Chua, G.; Khan, S.; Gallie, B.L.; Hughes, T.R.; Blencowe, B.J.; Frey, B.J.; Morris, Q.D. Using expression profiling data to identify human microRNA targets. Nat. Methods 2007, 4, 1045-1049. [CrossRef] [PubMed]

94. Adam, L.; Zhong, M.; Choi, W.; Qi, W.; Nicoloso, M.; Arora, A.; Calin, G.; Wang, H.; Siefker-Radtke, A.; McConkey, D.; et al. miR-200 expression regulates epithelial-to-mesenchymal transition in bladder cancer cells and reverses resistance to epidermal growth factor receptor therapy. Clin. Cancer Res. 2009, 15, 5060-5072. [CrossRef] [PubMed]

95. Ichimi, T.; Enokida, H.; Okuno, Y.; Kunimoto, R.; Chiyomaru, T.; Kawamoto, K.; Kawahara, K.; Toki, K.; Kawakami, K.; Nishiyama, K.; et al. Identification of novel microRNA targets based on microRNA signatures in bladder cancer. Int. J. Cancer 2009, 125, 345-352. [CrossRef] [PubMed] 
96. Dyrskjot, L.; Ostenfeld, M.S.; Bramsen, J.B.; Silahtaroglu, A.N.; Lamy, P.; Ramanathan, R.; Fristrup, N.; Jensen, J.L.; Andersen, C.L.; Zieger, K.; et al. Genomic profiling of microRNAs in bladder cancer: miR-129 is associated with poor outcome and promotes cell death in vitro. Cancer Res. 2009, 69, 4851-4860. [CrossRef] [PubMed]

97. Lin, T.; Dong, W.; Huang, J.; Pan, Q.; Fan, X.; Zhang, C.; Huang, L. MicroRNA-143 as a tumor suppressor for bladder cancer. J. Urol. 2009, 181, 1372-1380. [CrossRef] [PubMed]

98. Liu, S.; Ginestier, C.; Ou, S.J.; Clouthier, S.G.; Patel, S.H.; Monville, F.; Korkaya, H.; Heath, A.; Dutcher, J.; Kleer, C.G.; et al. Breast cancer stem cells are regulated by mesenchymal stem cells through cytokine networks. Cancer Res. 2011, 71, 614-624. [CrossRef] [PubMed]

99. Andrews, B.; Shariat, S.F.; Kim, J.H.; Wheeler, T.M.; Slawin, K.M.; Lerner, S.P. Preoperative plasma levels of interleukin- 6 and its soluble receptor predict disease recurrence and survival of patients with bladder cancer. J. Urol. 2002, 167, 1475-1481. [CrossRef]

100. Chen, M.F.; Lin, P.Y.; Wu, C.F.; Chen, W.C.; Wu, C.T. IL-6 expression regulates tumorigenicity and correlates with prognosis in bladder cancer. PLoS ONE 2013, 8, e61901. [CrossRef] [PubMed]

101. Bostrom, P.J.; Aaltonen, V.; Soderstrom, K.O.; Uotila, P.; Laato, M. Expression of cyclooxygenase-1 and -2 in urinary bladder carcinomas in vivo and in vitro and prostaglandin E2 synthesis in cultured bladder cancer cells. Pathology 2001, 33, 469-474. [CrossRef] [PubMed]

102. Gakis, G. The role of inflammation in bladder cancer. Adv. Exp. Med. Biol. 2014, 816, 183-196. [PubMed]

103. Tata, P.R.; Mou, H.; Pardo-Saganta, A.; Zhao, R.; Prabhu, M.; Law, B.M.; Vinarsky, V.; Cho, J.L.; Breton, S.; Sahay, A.; et al. Dedifferentiation of committed epithelial cells into stem cells in vivo. Nature 2013, 503, 218-223. [CrossRef] [PubMed]

104. Friedmann-Morvinski, D.; Verma, I.M. Dedifferentiation and reprogramming: Origins of cancer stem cells. EMBO Rep. 2014, 15, 244-253. [CrossRef] [PubMed]

105. Black, P.C.; Brown, G.A.; Dinney, C.P. The impact of variant histology on the outcome of bladder cancer treated with curative intent. Urol. Oncol. 2009, 27, 3-7. [CrossRef] [PubMed]

106. Lagwinski, N.; Thomas, A.; Stephenson, A.J.; Campbell, S.; Hoschar, A.P.; El-Gabry, E.; Dreicer, R.; Hansel, D.E. Squamous cell carcinoma of the bladder: A clinicopathologic analysis of 45 cases. Am. J. Surg. Pathol. 2007, 31, 1777-1787. [CrossRef] [PubMed]

107. Cheng, L.; Pan, C.X.; Yang, X.J.; Lopez-Beltran, A.; MacLennan, G.T.; Lin, H.; Kuzel, T.M.; Papavero, V.; Tretiakova, M.; Nigro, K.; et al. Small cell carcinoma of the urinary bladder: A clinicopathologic analysis of 64 patients. Cancer 2004, 101, 957-962. [CrossRef] [PubMed]

108. Choi, W.; Porten, S.; Kim, S.; Willis, D.; Plimack, E.R.; Hoffman-Censits, J.; Roth, B.; Cheng, T.; Tran, M.; Lee, I.L.; et al. Identification of distinct basal and luminal subtypes of muscle-invasive bladder cancer with different sensitivities to frontline chemotherapy. Cancer Cell 2014, 25, 152-165. [CrossRef] [PubMed]

109. Kim, S.P.; Frank, I.; Cheville, J.C.; Thompson, R.H.; Weight, C.J.; Thapa, P.; Boorjian, S.A. The impact of squamous and glandular differentiation on survival after radical cystectomy for urothelial carcinoma. J. Urol. 2012, 188, 405-409. [CrossRef] [PubMed]

110. Mitra, A.P.; Bartsch, C.C.; Bartsch, G., Jr.; Miranda, G.; Skinner, E.C.; Daneshmand, S. Does presence of squamous and glandular differentiation in urothelial carcinoma of the bladder at cystectomy portend poor prognosis? An intensive case-control analysis. Urol. Oncol. 2014, 32, 117-127. [CrossRef] [PubMed]

111. Atkin, N.B. Premature chromosome condensation in carcinoma of the bladder: Presumptive evidence for fusion of normal and malignant cells. Cytogenet. Cell Genet. 1979, 23, 217-219. [CrossRef] [PubMed]

112. Kovacs, G. Premature chromosome condensation: Evidence for in vivo cell fusion in human malignant tumours. Int. J. Cancer 1985, 36, 637-641. [CrossRef] [PubMed]

113. Duelli, D.; Lazebnik, Y. Cell-to-cell fusion as a link between viruses and cancer. Nat. Rev. Cancer 2007, 7, 968-976. [CrossRef] [PubMed]

114. Mullins, C.S.; Linnebacher, M. Endogenous retrovirus sequences as a novel class of tumor-specific antigens: An example of HERV-H env encoding strong CTL epitopes. Cancer Immunol. Immunother. CII 2012, 61, 1093-1100. [CrossRef] [PubMed]

115. Gasent Blesa, J.; Candel, V. Cell-cell fusion as a potential target in cancer therapy. Ecancermed. Sci. $2009,3$. [CrossRef] [PubMed] 
116. Yu, H.; Liu, T.; Zhao, Z.; Chen, Y.; Zeng, J.; Liu, S.; Zhu, F. Mutations in 3'-long terminal repeat of HERV-W family in chromosome 7 upregulate syncytin-1 expression in urothelial cell carcinoma of the bladder through interacting with c-Myb. Oncogene 2014, 33, 3947-3958. [CrossRef] [PubMed]

117. Gabriel, U.; Steidler, A.; Trojan, L.; Michel, M.S.; Seifarth, W.; Fabarius, A. Smoking increases transcription of human endogenous retroviruses in a newly established in vitro cell model and in normal urothelium. AIDS Res. Hum. Retrovir. 2010, 26, 883-888. [CrossRef] [PubMed]

118. Bergsmedh, A.; Szeles, A.; Henriksson, M.; Bratt, A.; Folkman, M.J.; Spetz, A.L.; Holmgren, L. Horizontal transfer of oncogenes by uptake of apoptotic bodies. Proc. Natl. Acad. Sci. USA 2001, 98, 6407-6411. [CrossRef] [PubMed]

119. Noubissi, F.K.; Harkness, T.; Alexander, C.M.; Ogle, B.M. Apoptosis-induced cancer cell fusion: A mechanism of breast cancer metastasis. FASEB J. 2015, 29, 4036-4045. [CrossRef] [PubMed]

120. Dittmar, T.; Schwitalla, S.; Seidel, J.; Haverkampf, S.; Reith, G.; Meyer-Staeckling, S.; Brandt, B.H.; Niggemann, B.; Zanker, K.S. Characterization of hybrid cells derived from spontaneous fusion events between breast epithelial cells exhibiting stem-like characteristics and breast cancer cells. Clin. Exp. Metastasis 2011, 28, 75-90. [CrossRef] [PubMed]

121. Wang, R.; Sun, X.; Wang, C.Y.; Hu, P.; Chu, C.Y.; Liu, S.; Zhau, H.E.; Chung, L.W. Spontaneous cancer-stromal cell fusion as a mechanism of prostate cancer androgen-independent progression. PLoS ONE 2012, 7, e42653. [CrossRef] [PubMed]

122. Jacobsen, B.M.; Harrell, J.C.; Jedlicka, P.; Borges, V.F.; Varella-Garcia, M.; Horwitz, K.B. Spontaneous fusion with, and transformation of mouse stroma by, malignant human breast cancer epithelium. Cancer Res. 2006, 66, 8274-8279. [CrossRef] [PubMed]

123. Powell, A.E.; Anderson, E.C.; Davies, P.S.; Silk, A.D.; Pelz, C.; Impey, S.; Wong, M.H. Fusion between Intestinal epithelial cells and macrophages in a cancer context results in nuclear reprogramming. Cancer Res. 2011, 71, 1497-1505. [CrossRef] [PubMed]

124. Duelli, D.; Lazebnik, Y. Cell fusion: A hidden enemy? Cancer Cell 2003, 3, 445-448. [CrossRef]

125. Jinesh, G.G.; Choi, W.; Shah, J.B.; Lee, E.K.; Willis, D.L.; Kamat, A.M. Blebbishields, the emergency program for cancer stem cells: Sphere formation and tumorigenesis after apoptosis. Cell Death Differ. 2013, 20, 382-395. [CrossRef] [PubMed]

126. Li, F.; Tiede, B.; Massague, J.; Kang, Y. Beyond tumorigenesis: Cancer stem cells in metastasis. Cell Res. 2007, 17, 3-14. [CrossRef] [PubMed]

127. Vignery, A. Macrophage fusion: Are somatic and cancer cells possible partners? Trends Cell Biol. 2005, 15, 188-193. [CrossRef] [PubMed]

128. Rizvi, A.Z.; Swain, J.R.; Davies, P.S.; Bailey, A.S.; Decker, A.D.; Willenbring, H.; Grompe, M.; Fleming, W.H.; Wong, M.H. Bone marrow-derived cells fuse with normal and transformed intestinal stem cells. Proc. Natl. Acad. Sci. USA 2006, 103, 6321-6325. [CrossRef] [PubMed]

129. Saxman, S.B.; Propert, K.J.; Einhorn, L.H.; Crawford, E.D.; Tannock, I.; Raghavan, D.; Loehrer, P.J., Sr.; Trump, D. Long-term follow-up of a phase III intergroup study of cisplatin alone or in combination with methotrexate, vinblastine, and doxorubicin in patients with metastatic urothelial carcinoma: A cooperative group study. J. Clin. Oncol. 1997, 15, 2564-2569. [PubMed]

130. Massari, F.; Ciccarese, C.; Santoni, M.; Brunelli, M.; Conti, A.; Modena, A.; Montironi, R.; Santini, D.; Cheng, L.; Martignoni, G.; et al. The route to personalized medicine in bladder cancer: Where do we stand? Targeted Oncol. 2015, 10, 325-336. [CrossRef] [PubMed]

131. Koga, F.; Kihara, K.; Neckers, L. Inhibition of cancer invasion and metastasis by targeting the molecular chaperone heat-shock protein 90. Anticancer Res. 2009, 29, 797-807. [PubMed]

132. Sauvageot, C.M.; Weatherbee, J.L.; Kesari, S.; Winters, S.E.; Barnes, J.; Dellagatta, J.; Ramakrishna, N.R.; Stiles, C.D.; Kung, A.L.; Kieran, M.W.; et al. Efficacy of the HSP90 inhibitor 17-AAG in human glioma cell lines and tumorigenic glioma stem cells. Neuro Oncol. 2009, 11, 109-121. [CrossRef] [PubMed]

133. Newman, B.; Liu, Y.; Lee, H.F.; Sun, D.; Wang, Y. HSP90 inhibitor 17-AAG selectively eradicates lymphoma stem cells. Cancer Res. 2012, 72, 4551-4561. [CrossRef] [PubMed]

134. Tatokoro, M. heat shock protein 90 targeting therapy: State of the art and future perspective. EXCLI J. 2015, 14, 48-58. [PubMed] 
135. Ito, M.; Liu, Y.; Yang, Z.; Nguyen, J.; Liang, F.; Morris, R.J.; Cotsarelis, G. Stem cells in the hair follicle bulge contribute to wound repair but not to homeostasis of the epidermis. Nat. Med. 2005, 11, 1351-1354. [CrossRef] [PubMed]

136. Kurtova, A.V.; Xiao, J.; Mo, Q.; Pazhanisamy, S.; Krasnow, R.; Lerner, S.P.; Chen, F.; Roh, T.T.; Lay, E.; Ho, P.L.; et al. Blocking PGE2-induced tumour repopulation abrogates bladder cancer chemoresistance. Nature 2015, 517, 209-213. [CrossRef] [PubMed]

137. Redelman-Sidi, G.; Glickman, M.S.; Bochner, B.H. The mechanism of action of BCG therapy for bladder cancer-A current perspective. Nat. Rev. Urol. 2014, 11, 153-162. [CrossRef] [PubMed]

138. Powles, T.; Eder, J.P.; Fine, G.D.; Braiteh, F.S.; Loriot, Y.; Cruz, C.; Bellmunt, J.; Burris, H.A.; Petrylak, D.P.; Teng, S.L.; et al. MPDL3280A (anti-PD-L1) treatment leads to clinical activity in metastatic bladder cancer. Nature 2014, 515, 558-562. [CrossRef] [PubMed]

139. Chan, K.S.; Volkmer, J.P.; Weissman, I. Cancer stem cells in bladder cancer: A revisited and evolving concept. Curr. Opin. Urol. 2010, 20, 393-397. [CrossRef] [PubMed]

140. Shay, J.W.; Bacchetti, S. A survey of telomerase activity in human cancer. Eur. J. Cancer 1997, 33, 787-791. [CrossRef]

141. Ju, Z.; Rudolph, K.L. Telomeres and telomerase in cancer stem cells. Eur. J. Cancer 2006, 42, 1197-1203. [CrossRef] [PubMed]

142. Castelo-Branco, P.; Zhang, C.; Lipman, T.; Fujitani, M.; Hansford, L.; Clarke, I.; Harley, C.B.; Tressler, R.; Malkin, D.; Walker, E.; et al. Neural tumor-initiating cells have distinct telomere maintenance and can be safely targeted for telomerase inhibition. Clin. Cancer Res. 2011, 17, 111-121. [CrossRef] [PubMed]

143. Shay, J.W.; Wright, W.E. Telomeres and telomerase in normal and cancer stem cells. FEBS Lett. 2010, 584, 3819-3825. [CrossRef] [PubMed]

144. Hirashima, K.; Migita, T.; Sato, S.; Muramatsu, Y.; Ishikawa, Y.; Seimiya, H. Telomere length influences cancer cell differentiation in vivo. Mol. Cell. Biol. 2013, 33, 2988-2995. [CrossRef] [PubMed]

145. Joseph, I.; Tressler, R.; Bassett, E.; Harley, C.; Buseman, C.M.; Pattamatta, P.; Wright, W.E.; Shay, J.W.; Go, N.F. The telomerase inhibitor imetelstat depletes cancer stem cells in breast and pancreatic cancer cell lines. Cancer Res. 2010, 70, 9494-9504. [CrossRef] [PubMed]

146. Borah, S.; Xi, L.; Zaug, A.J.; Powell, N.M.; Dancik, G.M.; Cohen, S.B.; Costello, J.C.; Theodorescu, D.; Cech, T.R. Cancer. TERT promoter mutations and telomerase reactivation in urothelial cancer. Science 2015, 347, 1006-1010. [CrossRef] [PubMed]

147. Li, C.; Wu, S.; Wang, H.; Bi, X.; Yang, Z.; Du, Y.; He, L.; Cai, Z.; Wang, J.; Fan, Z. The C228T mutation of TERT promoter frequently occurs in bladder cancer stem cells and contributes to tumorigenesis of bladder cancer. Oncotarget 2015, 6, 19542-19551. [CrossRef] [PubMed]

148. Dikmen, Z.G.; Wright, W.E.; Shay, J.W.; Gryaznov, S.M. Telomerase targeted oligonucleotide thio-phosphoramidates in T24-luc bladder cancer cells. J. Cell. Biochem. 2008, 104, 444-452. [CrossRef] [PubMed]

149. Kraemer, K.; Fuessel, S.; Schmidt, U.; Kotzsch, M.; Schwenzer, B.; Wirth, M.P.; Meye, A. Antisense-mediated hTERT inhibition specifically reduces the growth of human bladder cancer cells. Clin. Cancer Res. 2003, 9, 3794-3800. [PubMed]

150. Gudas, L.J.; Wagner, J.A. Retinoids regulate stem cell differentiation. J. Cell. Physiol. 2011, 226, 322-330. [CrossRef] [PubMed]

151. Kashyap, V.; Gudas, L.J.; Brenet, F.; Funk, P.; Viale, A.; Scandura, J.M. Epigenomic reorganization of the clustered Hox genes in embryonic stem cells induced by retinoic acid. J. Biol. Chem. 2011, 286, 3250-3260. [CrossRef] [PubMed]

152. Connolly, R.M.; Nguyen, N.K.; Sukumar, S. Molecular pathways: Current role and future directions of the retinoic acid pathway in cancer prevention and treatment. Clin. Cancer Res. 2013, 19, 1651-1659. [CrossRef] [PubMed]

153. Huang, M.E.; Ye, Y.C.; Chen, S.R.; Chai, J.R.; Lu, J.X.; Zhoa, L.; Gu, L.J.; Wang, Z.Y. Use of all-trans retinoic acid in the treatment of acute promyelocytic leukemia. Blood 1988, 72, 567-572. [PubMed]

154. Campos, B.; Wan, F.; Farhadi, M.; Ernst, A.; Zeppernick, F.; Tagscherer, K.E.; Ahmadi, R.; Lohr, J.; Dictus, C.; Gdynia, G.; et al. Differentiation therapy exerts antitumor effects on stem-like glioma cells. Clin. Cancer Res. 2010, 16, 2715-2728. [CrossRef] [PubMed] 
155. Moro, M.; Bertolini, G.; Pastorino, U.; Roz, L.; Sozzi, G. Combination treatment with all-trans retinoic acid prevents cisplatin-induced enrichment of $\mathrm{CD} 133^{+}$tumor-initiating cells and reveals heterogeneity of cancer stem cell compartment in lung cancer. J. Thorac. Oncol. 2015, 10, 1027-1036. [CrossRef] [PubMed]

156. Gandhi, D.; Molotkov, A.; Batourina, E.; Schneider, K.; Dan, H.; Reiley, M.; Laufer, E.; Metzger, D.; Liang, F.; Liao, Y.; et al. Retinoid signaling in progenitors controls specification and regeneration of the urothelium. Dev. Cell 2013, 26, 469-482. [CrossRef] [PubMed]

157. Hameed, D.A.; El-Metwally, T.H. The effectiveness of retinoic acid treatment in bladder cancer: Impact on recurrence, survival and TGF $\alpha$ and VEGF as end-point biomarkers. Cancer Biol. Ther. 2008, 7, 92-100. [CrossRef] [PubMed]

158. Takebe, N.; Harris, P.J.; Warren, R.Q.; Ivy, S.P. Targeting cancer stem cells by inhibiting Wnt, Notch, and Hedgehog pathways. Nat. Rev. Clin. Oncol. 2011, 8, 97-106. [CrossRef] [PubMed]

159. Urakami, S.; Shiina, H.; Enokida, H.; Kawakami, T.; Tokizane, T.; Ogishima, T.; Tanaka, Y.; Li, L.C.; Ribeiro-Filho, L.A.; Terashima, M.; et al. Epigenetic inactivation of Wnt inhibitory factor-1 plays an important role in bladder cancer through aberrant canonical Wnt/ $\beta$-catenin signaling pathway. Clin. Cancer Res. 2006, 12, 383-391. [CrossRef] [PubMed]

160. Ikushima, H.; Todo, T.; Ino, Y.; Takahashi, M.; Saito, N.; Miyazawa, K.; Miyazono, K. Glioma-initiating cells retain their tumorigenicity through integration of the Sox axis and Oct4 protein. J. Biol. Chem. 2011, 286, 41434-41441. [CrossRef] [PubMed]

161. Shariat, S.F.; Kim, J.H.; Andrews, B.; Kattan, M.W.; Wheeler, T.M.; Kim, I.Y.; Lerner, S.P.; Slawin, K.M. Preoperative plasma levels of transforming growth factor $\beta_{1}$ strongly predict clinical outcome in patients with bladder carcinoma. Cancer 2001, 92, 2985-2992. [CrossRef]

162. Geng, J.; Fan, J.; Ouyang, Q.; Zhang, X.; Zhang, X.; Yu, J.; Xu, Z.; Li, Q.; Yao, X.; Liu, X.; et al. Loss of PPM1A expression enhances invasion and the epithelial-to-mesenchymal transition in bladder cancer by activating the TGF- $\beta$ /Smad signaling pathway. Oncotarget 2014, 5, 5700-5711. [CrossRef] [PubMed]

163. Principe, D.R.; Doll, J.A.; Bauer, J.; Jung, B.; Munshi, H.G.; Bartholin, L.; Pasche, B.; Lee, C.; Grippo, P.J. TGF- $\beta$ : Duality of function between tumor prevention and carcinogenesis. J. Natl. Cancer Inst. 2014, 106. [CrossRef] [PubMed]

164. Kreso, A.; van Galen, P.; Pedley, N.M.; Lima-Fernandes, E.; Frelin, C.; Davis, T.; Cao, L.; Baiazitov, R.; Du, W.; Sydorenko, N.; et al. Self-renewal as a therapeutic target in human colorectal cancer. Nat. Med. 2014, 20, 29-36. [CrossRef] [PubMed]

165. Zhu, D.; Wan, X.; Huang, H.; Chen, X.; Liang, W.; Zhao, F.; Lin, T.; Han, J.; Xie, W. Knockdown of Bmi1 inhibits the stemness properties and tumorigenicity of human bladder cancer stem cell-like side population cells. Oncol. Rep. 2014, 31, 727-736. [PubMed] 